\title{
Impact of Capital Market on the Development of the Nigerian Economy
}

\author{
Stephen Bassey Duke \\ Ph.D Scholar Department of Banking and finance \\ University of Calabar, Cross River State Nigeria \\ Nkamare S. E. \\ PHd Scholar Department of Banking and finance \\ University of Calabar, Cross River State Nigeria
}

\begin{abstract}
This study attempts to investigate the performance of the Nigeria capital market and the growth of Nigerian economy from 1986-2005. Data on stocks were modeled to test for the relationship between market capitalization, the number of stock traded in the capital market and development in the economy (GDP). A multiple regression analysis involving the ordinary least squares estimation technique was employed to discover the composite effect of capital market indices such as government stocks, industrial stocks and equities on the development of the economy during the twenty years in review. The multiple correlation coefficients which measured the strength of association between the economic development and capital market performance was positive, indicating that there was a direct perfect relationship among the variables. The result also indicates that none of the variables (predictors) individually predicted GDP. In spite of the enormous opportunities provided by the ongoing reforms and the booming economy, the capital market in Nigeria has performed below its potentials owing to a number of factors. Accordingly, it was recommended that there should be a strong need to put in place policy measures that would guarantee competitive participation and cause investors to stop the attitude of "buy and hold" of securities which will delay rapid development of Nigerian economy.
\end{abstract}

keywords: Capital market, Gross domestic product, debt securities, market capitalization etc

\section{Background to the study}

\section{CHAPTER ONE - INTRODUCTION}

Developing countries all over the world are researching on how to solve major economic problems of inadequacy of capital resources for the purpose of enhancing economic growth and development.

Capital is indeed needed to propel the engine of growth and thus, facilitating maximum output and real economic growth in an economy. An assessment of the entire economic system reveals that capital due to the nations are not properly harnessed in developing countries due to the presence of weak capital markets and inefficient infrastructure to mobilize available capital for economic and productive activities. (Nzotta, 2004) 
A capital market is therefore a network of financial institutions that facilitate the mobilization and allocation of medium and long-term funds in an economy. The long term funds are used for financial assets issued by borrowers or traded by holder of outstanding eligible instruments. Therefore, it provides services that are essential to a modern economy, mainly by contributing to capital formation through financial intermediation, financial advisory services and managerial skill development.

Before the advent of the stock market, banks and other money market institutions in Nigeria provided short-term funds to businesses. Money market institutions traditionally lend shortterm funds which are not suitable for the funding of long term projects with long gestation periods, such as industries, infrastructures, power generation and telecommunication. Power generation is known to require huge and long term fund which only the stock market is in a more convenient position to provide. A stock market thus, constitutes the hub and the accelerator of a rapidly industrializing economy. It affords an enterprise the opportunity to broaden economies of scale and skill and high fly international profile (Onoh, 2002).

The equity markets in developing countries until the mid 1980s generally suffered from the classical defects of bank-dominated economies, that is, shortage of equity capital, lack of liquidity, absence of foreign institutional investors, and lack of investors' confidence in the stock market. Since 1986, the stock markets of developing nations have witnessed appreciable development with financial liberalization and the easing of legislative and administrative barriers coupled with the adoption of tougher regulations to boost investors' confidence. With the beginning of financial liberalization in the developing countries, the flow of private foreign capital from the developed to the developing countries has increased significantly and such inflows of foreign capital have been mainly in the form of foreign direct and portfolio investment (World Bank, 1996 \& Agarwal, 1997). The latter type of inflows has mainly been through the stock market.

In Nigeria, with the inception of the Structural Adjustment Programme in 1986, the financial sector has experienced tremendous change as privatization has is one of the basic tenets of the programme. No doubt, privatization has strengthened stock market development by increasing the quality and quantity of financial instruments traded in the market. By 1997, some efforts were made of minimize the risk of capital investment in the Nigerian economy by putting in place relevant institutions to minimize clearing, depository and settlement problems. Hence, the Central Securities and Clearing System (CSCS) came into being then. This, in conjunction with automated trading, has improved the performance of the market. Coincidentally, since the beginning of financial liberalization in 1986, Nigeria has made a remarkable turnaround with the GDP growth rising from negative of 0.3 percent in 1982, to 3.2 and 8.2 percent in 1986 and 1990 respectively. The growth rate of GDP, though declined to 1.3 percent in 1994, picked and rose smoothly to 3.4 percent in 1996.

Stock market facilitates efficient allocation of resources to the appropriate users. It also enhances higher productivity and better realization for macro-economic goals such as price stability, higher level of savings, greater export opportunities, more employment opportunities, and a higher standard of living for the populace.

The instruments traded in the market include government securities, corporate bonds, shares and mortgage loans (Anyanwu, et al., 1997). Participants in the Nigerian stock market include the Nigerian Stock Exchange, (NSE) Discount Houses, Development Banks, Merchant banks, Stock Broking Firms, Insurance and Pension Organisations, quoted companies, Governments at all levels, individuals and the Nigerian Securities and Exchange Commission (NSEC). 
Stock market consists of the primary market, which is concerned with the offering of new issues or the initial issuance and sale of securities. Previously, quoted companies could seek expansion of funds through the issuance of supplementary securities in this market while new companies were required to go public before they could issue securities to the public through the market. Types of instruments issued here include debt instruments comprising federal government development stocks (FOSs), and industrial loans and bonds issued by corporate bodies and equity capital (ordinary shares of corporate entities) which confer upon the holders some ownership rights to the business concerned.

The secondary market, thus, trades on securities that have already been listed on the stock exchange. It is often contended that the existence and allocative efficiency of the primary market is, however, dependent upon the existence and efficiency of the secondary market in all respects (Mbat, 2001).

Although, the stock market is neither a private nor public sector institution, it assists in the transmission of government policy to all the sectors of the economy, especially in economies, where the authorities consciously influence the direction of the economy.

\section{Statement of the Problem}

The Nigerian economy is going through a transformation process, aimed at achieving economic growth and development. The role of the capital market in this regard cannot be over emphasized for capital is a critical factor in any economic transaction. Thus, the ability of a nation to mobilize savings and transform such savings into investment depends on the type of capital market that exists at a particular point in time. Suffice, to say that an efficient capital market is one which incorporates all the indices that allow for free flow of capital investments. The Nigerian capital Market since its inception has various problems which include among others, poor economic environment, which hampers a conducive investment to sustain vibrant capital market to the Nigerian economy; the problem of buy and hold strategy, whereby stocks are bought and locked up in a custody without being traded on the stock market. This strategy does not help to deepen the stock market. Equally, there is the fear of insider's abuses which helps to favour few investors than majority to take advantage of stock price movement in the share market.

The aforementioned problems restrain a good number of prospective investors and participants from being active players on the Nigerian stock market resulting from the poor performance of the capital market and the development of the Nigerian economy.

\section{The purpose of the Study}

The era of the Structural Adjustment Programme (SAP) introduced is 1986 had brought about the shifting of emphasis from the money markets to the capital markets, as an alternative source of long term finance. Most of the financially strong and better managed businesses in Nigeria saw this as a cheaper means of diverting risk because of the high interest rate in the money market. The incidence of high cost of capital in the money market also led to a great intermediation in the capital market and disintermediation in the money market.

The objectives of this study are:

1. To investigate the factors affecting the efficient performance of the Nigerian capital Market.

2. To evaluate the impact of the Nigeria capital market in the development of the Nigeria economy from 1986-2005. 


\section{Research Hypothesis}

For the purpose of this research study, the following null hypotheses would be tested.

1. Ho: There is no significant relationship between the performance of the Nigerian capital Market and the Development of the Nigerian Economy.

2. Ho: There is no significant relationship between the total number of stocks traded in the capital market and the development of the Nigerian economy between 1986 to 2005 .

\section{Significance of the Study}

This study is significant in that it will serve as an attempt in assessing the relationship between growth and stock market development in Nigeria. The capital Market is an important institution for enhancing investments activities and achieving rapid development of the economy. A detail research on the demand and supplies of capital is sin-quo-non as most industrial nations of the world would not have achieved the feat without developing an efficient capital market. In order to facilitate the mobilization of savings and investments that guarantee economic growth and development, there is need to have stock market in which there is a reasonable level of efficiency which will act as impetus to investors. These assertions summarizes the significance of this study as follows:

i. To articulate the awareness on other alternative source of funds and purchase of shares

ii. To help provide facilities for the quotation and ready marketability of shares and stocks and opportunities to raise fresh capital economic development.

iii. To provide opportunities locally for lending and borrowing for long term purposes

iv. To create a market for the Nigerian Government to mobilize long-term capital for economic development.

v. The study will redefine the share price boundaries within the context of proper pricing

vi. This study intends to elucidate the most salient of feature of capital market operations in Nigeria.

vii. The work and its findings will provide policy makers economic planners and Enterprises who wishes to invest in Nigeria a tool of appraisal of implication of capital Market in Nigeria.

viii. The outcome of the study is therefore expected to provide a basis on which further improvement in the operations of the capital market can be anchored. It is also expected to provide further insight into the peculiarities of the Nigerian capital market as a guide to policy makers.

\section{The limitation and Scope of the Study}

The study is on the performance of the Nigerian capital Market between 1986-2006 and the operations of the market which shall be and thus evaluating the activities of the capital markets and its contributions to the development of the Nigerian Economy.

This period is chosen because of the ever changing and dynamic nature of the Nigerian financial landscape in general and the operations of the Nigerian capital Market in particular. However, using the study or work the chosen sample is representative enough for valid generalization about the performance of the capital market in the development of Nigeria. The study will research on the operating instruments using some or all the following criteria:

i. Market capitalization showing the total value of all listed shares in the capital market

ii. Number of listed securities which shows the volume of securities in the capital market within the period

iii. All share price index which measures the performance of the market computer on daily basis.

iv. The Gross Domestic Product GDP 


\section{Organisation of the Study}

This research study is basically structured into five chapters. Chapter one is the introduction and background of the study, statement of the problems, purpose of the study, research questions, research hypothesis, significance of the study, scope of study, organisation of study and definitions of terms.

Chapter two captures the literature review. It delves on the development and structure of the capital market, concept of the capital market, operators of the capital market and the functions of the capital market. This chapter ends with the problems and achievements of Nigerian capital market.

Chapter three covers research methodology. The research design, the source of data, method of data collection and techniques of data analysis.

Chapter four focused on data presentations, analysis and discussion of findings. In this chapter hypothesis formulated were also tested.

Chapter five summarizes the study, draws conclusions and makes necessary recommendations.

\section{Definition of Concepts}

- Market Capitalization: Market capitalization is the aggregate market prices of all of a company's shares. It refers to the value of a firm as determined by the market price of its unused and outstanding common stocks. It represents one of the ways to categorize stocks in the market. (Nzotta, 2004).

- Capital Market: This market is concerned with the mobilization and intermediation of long term funds. It provides a mechanism for lenders to provide long term funds in exchange for financial assets issued by borrowers or traded by holders of outstanding negotiable debt instruments (Nwankwo, 1980).

- Money Market: According to Onyido (1994), the money market is the market for short term funds and securities, with securities of less than one year the term is often used to describe or define the network of borrowers and lenders for short term funds. The money market primarily exists as a means of liquidity adjustments while the capital market provides the bridge by which the savings of surplus units may be transformed into medium and long-term investments in defiant units.

- Second-tier securities market (SSM): This is a market where shares of companies that are not fully listed are traded, but which is regulated by the stock exchange (Adetunji, 1977).

- Securitization: This is the process of converting assets into marketable securities. Documentation (Certificate) which shows ownership of a property (bonds stocks and shares) government security for money lent to it (Mbat, 2001:2)

- Capital Market: A forum through which medium to long-term loanable funds are obtained (Mbat, 2001:38).

- SEC: Securities and Exchange Commission

- NSE: Nigerian Stock Exchange

- Investment: The commitment of resources into a business with the aim of realization profits or returns.

- Common Stock Equity Securities: Officially issued to shareholders who have voting rights? Their rights may attract dividends resulting from profits of the public corporation (Mbat, 2001:94).

- FSM: First Tier Securities Market 
- SSM: Second Securities Market

- Investment Portfolio: A set of investible securities chosen by an investor (Mbat, 2001)

\section{Theoretical Framework}

\section{CHAPTER TWO LITERATURE REVIEW}

The capital market exists for the mobilization and intermediation of long term funds between areas of deficit and surplus economic units. Both lenders and borrowers of long term funds meet here to transact business (Babalola, 2001:3).

The capital market is the platform on which fortunes growth and development and serves as an indicator of the economy's liquidity and general performance (Osaze, 1997). It is also the market for other securities like corporate stocks and shares and bonds (Briston, 1969).

The instruments constitute the permanent financing of any company hence these long-term nature last longer than 3 to 5 years. It accommodates instruments such as government development stocks and bonds which are normally referred to as gilt-edge securities.

Giwa (1990) in his view perceived that the Capital Market is a market in which the govemment, banks, companies etc. can invest or borrow usually large sum of money on a long term basis. Capital Market are referred to as 'securities'

The capital market is a subset of the financial system that serves as the engine for growth in modem economies. It is that part of the financial system that is involved in providing long term fund for productive use. The capital market can also be looked at as a network of institutions and individuals made up of regulators and operators who together facilitates the smooth operations of the market (Okereke, 2000: 1). There are basically three major schools of thought:

- The efficient market hypothesis

- The fundamental theorist

- The technical analysis (Lumby, 1994:368).

\section{Efficient Market Hypothesis}

It is generally expected that financial markets should behave in accordance with the efficient market hypothesis. Technical and fundamental analyses fall short of this expectation and were believed to follow a random walk design. These issues attracted heavy criticism by the academics.

Empirical support for the view that share prices do not behave in a systematic manner but are more akin to random walk was initially put forward by Professor M.G. Kendall in the 1950s. Kendall (1953) in a study of the behaviour of share prices confirmed this situation. Fama (1970) equally supported this view and thus threw more light on the matter by defining random walk to mean "successive price changes that are independent of each other, that is, they are uncorrelated, hence, attempting to predict the next movement in a particular time series becomes impossible by a study of previous movements.

There has, as a consequence, been a degree of antagonism between chartists and academic supporters of the random walk idea (Levy, 1967).

The Efficient market hypothesis supplies a theoretical framework which lends support to the random walk character of share prices. But what exactly do we mean by an "efficient" market? 
An efficient market is one where at any time prices take into account all available information, market participants are assumed to act in an intelligent, self-motivated manner and to assess and act upon available information about share prices when information about a specific share is not acted upon then an opportunity will arise for at least some market participants to use that information to their advantage by buying or selling the share. (Mbat et al, 2004).

Analysts classify market efficiency into three possible varieties:

- Weak form efficiency; in which all prices are said to reflect all past information;

- Semi-strong form efficiency; in which prices fully reflect all publicly available information;

- Strong form efficiency; where prices are said to embody all information, whether or not publicly available.

\section{Weak efficiency market}

In Lumby (1994:370) and Foley (1999:32), the weak form of efficiency market is a sufficient condition to undermine technical analysts claim to be able to generate consistently higher profits of making use of charts of past price movements.

As far as weak efficiency is concerned, empirical evidence show that share prices tend to follow a random walk. This term can be misleading, in that it gives the impression that share prices move at random, without any reason. In fact, random walk means almost the opposite of this common sense interpretation; if share prices follow a random walk, the implication is that share prices only move in response to the disclosure of new information that is relevant to their value. Such as the disclosure of the annual profits or the announcement of a major new customer. Random walk therefore implies that share prices move only when they have gotten good reasons to move. If there is any known reason of non-random movements in share prices, it implies that the market is inefficient because share prices are moving when they have not gotten good reason to do so.

If share prices do follow a random walk, it then follows that technical analysis is worthless, in that it cannot have any predictive power; which is by definition, anything which moves at random cannot be predicted.

\section{Schiller's volatility test}

There is one very interesting piece of evidence that does so against the idea of weak efficiency. This is known as Schiller's volatility tests. Schiller argues that in an efficient market, you would expect share prices to be too volatile to be truly random. In other words, Schiller is casting doubt on whether share price movements are always a justifiable response to the information that was being disclosed. However, Schiller is just about the only researcher to question whether the market is truly weakly efficient.

\section{Semi-strong efficiency}

The semi-strong form of the EMH takes us one step further by arguing that not only is part information taken into account so too is all publicly available information. There is considerable evidence that most of the major stock markets are efferent in the weak form of the hypothesis and some are consistent with semi-strong form (Lumby, 1994:371).

\section{Strong efficiency}

In the case of a market characterized by strong efficiency it would be impossible for an investor to take advantage of new information from whatever sources. This is because a market 
operating at this level of efficiency already exploits all information relevant to the share. This in turn means that insider information will also have been included in determining the share price.

While the strong form of the market efficiency hypothesis has little empirical support, it may be influential in affecting perceptions of how markets should operate (Foley, 1999:32).

\section{Anomalies of efficient market hypothesis (EMH)}

A key feature of EMH is that an efficient market is not possible to make consistently higher returns except by holding a portfolio with a higher level of risk. However anomalies emerged because of the following reasons:

i. The small firm's effect or the smaller companies puzzle. Here, evidence is available on the existence of consistently higher returns from investing in the shares of smaller companies (Foley, 1999). In the United States and the United Kingdom, acknowledged to have the most informationally efficient stock markets in the world.

ii. Seasonal Variation in Returns: the so-called January effect came to light in 1984 (Kein, 1984). This showed that in the US, nearly all the differential size effect occurs at the turn of the year that is during the early part of January. Similar seasonal effects have been identified in other markets.

This constitutes a further puzzle, the very thing which random walk theory seemed to dismiss; the existence of persistent and replicable market behaviour seems to have risen from the dead. It is right to argue that the seasonal patterns as they apply to segments of the market or to market patterns as they apply to segments of the market or to market indexes rather than individual share prices but it still leaves a fairly uncomfortable problem for proponents of the $\mathrm{EMH}$. If the market is informationally efficient, why do seasonal regularities occur and why do market participate occur and why do market participants fail to exploit and thereby eliminate these seasonal effects? One possibility is that the abnormalities are there but are simply below an exploitable level. Share transactions are subject to dealing costs and hence if the disparities in returns are insufficiently large, then trading will not be able to take advantage of such effects. In this case, we would observe that existence of a variety of so-called irrational seasonal effects but these would be quite compatible with a slightly modified form of the EMH (Keane, 1989).

\section{Fundamental Theory}

According to Professor Uegene Fama of University of Chicago graduate School in 1960 states that, at any point in time an individual security has an intrinsic or true value, which is the present value of the future receipts accruing to the security holder. The theory also holds that, the intrinsic, value of the security depends on some essential factors affecting the company, the industry and the economy. The principal discussion variables in fundamental analysis are earning and dividends. Earning appends sales and costs, which are affected by several factors, internal and external to the firm's operating environment. Therefore, fundamentalist forecast stock prices on the basis of economic industry and company statistics. Fundamental analysis also attempts to identify factors influencing or likely to influence share prices, that is, the market reaction to information about the economy, industry and company. In assessing the company great reliance is placed on its published financial statement.

The other aspect of fundamental theory is that it tends to specialize in particular sectors of the stock market, about which they become extremely knowledgeable. They cast very wide information-capture net and then, on the basis of this information, and with the use of a share valuation model, determine what they think the shares and, if the analysis thinks the shares are 
worth more than the current market price, "buy" advice is given. Conversely, if the analysts believe the shares to be over-valued on the market, "sell" advice is given.

They are called fundamental analysts, because they look at the fundamental factors that lie behind a share's value: the revenues the company can be expected to generate, the costs that the company is expected to incur in the generation of those revenues, the uncertainty surrounding both the future costs and revenues finally, the price (or return) of comparable investments approaches are based on different notions about how share prices are determined and derive their investment philosophies accordingly.

\section{Technical analysis}

According to Lumby (1994:368) and Foley (1999:28) technical analysis also referred to as Chartism, study charts of share price movements, with the intention of discovering particular patterns and trend of share price movements which appear to recur. Once these patterns have been identified, following the share price movements of a particular company, and if they see one of these patterns staring to develop, they believe that they are then able to predict.

The share's future course of movement and so give buy or sell investment advice. Technical analysts believe that they have discovered hundreds of these recurring patterns, and thus give such names as "double tops, double bottoms, head and shoulders etc."

Technical analysis is faulty in that it does have any basis, nor does it want to investigate to known why a particular share price is predicted to rise or fall. All that is important is that the movement is indicative of a rise or a fall.

\section{Structure of the Capital Market in Nigeria}

Traditionally, a Capital Market is structured into the stock and commodities markets Hananna (2004). It is where financial assets such as shares, bonds are raised and traded. According to Mbat (2001) the commodity market is the segments of the capital market where commodities are traded. The commodities in their raw forms range from agricultural products to oil products and precious metals. A commodity exchange market operates a trading floor where the market operators transact their business. Thus, commodity and their derivatives are exchanged for money. Another important feature of the commodity market according to Akpan (2004) is that the commodities are not physically traded in pits and as such different commodities are traded in different pits. However, the commodities market is not well developed in Nigeria.

According to Akamiokhor (1992) the stock market is divided into the primary and secondary markets. The primary market is the segment of the stock market, where funds are sourced directly by investors from individuals, corporate organization and specialized development finance institutions. The main characteristics of the primary market are; the market is not identifiable with any particular site; and the proceeds go to the investor sourcing of fund from this segment of the capital market can either be in form of equity participation and or listed or unlisted industrial loans, mortgage loans and government bonds/stocks.

Levin (1996) noticed that the secondary segment is where existing securities are traded. Holders of particular securities or instruments purchased from the primary market may decide to sell instruments. The proceeds of sale go to the holders of the instruments than the company. In Nigeria, the secondary segment of the market is made up of two broad categories namely: the Centralized Action Market and the Dealers Market. The Dealers market is 
characterized by the absence of a centralized location for transacting business in securities. Thus, most securities not listed on the Nigerian Stock Exchange Account for the overwhelming majority of securities are traded in the dealers market. Other instruments traded in the dealers markets of the secondary segment of the capital are securities of unquoted companies primarily aimed at raising working capital. The Centralized Action Market is a stock exchange, which is an organized secondary market for buying and selling of securities. The hub of the Nigerian capital Market is the Stock Exchange. The Stock Exchange Operates two tiers, the first and second tier markets. Of the quoted equities in the market, are listed in the first tier market, 16 in the second tier and the remaining 4 in managed funds

\section{Equities market}

Mbat (2001) noticed that the market for equities in the Nigerian Stock Exchange consists of the first-tier and the second-tier equities. One important feature of the equities market is that subscription must be fully paid up before allotments are given to an individual investor. Other features of the equities market are part ownership by the subscribers immediately after allotment of the shares. Thus, holders of the instrument are entitled to attend the Annual General Meetings and can vote to elect the management. The return on equities is by way of dividend or price appreciation or scrip's issue. Unlike a debt instrument, repayment of the principal occurs only if the instrument is traded through the secondary market. The growth in total number of listed equities has not been impressive given the number of incorporated companies. From 153 in 1992, the number of listed ordinary shares peaked at 195 in 2002. (NSE, 2002). This development has been attributed largely, to the fact that an average Nigerian entrepreneur has an aversion to ownership dilution of his business, although this is a common phenomenon in all emerging stock market and developing economies.

\section{First tier securities market}

According to Anyanwu (1998) the first tier securities market deals with issues of quoted companies. The essential difference between the two tiers lies in their listing requirements. The listing requirements for the first tier market are:

1. The company must be registered as a public limited liability company under the provision of the companies and Allied Matters Act (1990) as amended;

2. At least 25 percent of the nominal value of share capital must be offered to the public.

3. The date of the last audited accounts must not be more than nine (9) months;

4. The company must submit to the exchange its financial statement and business records for the past five years.

5. The annual quoted fee payable by the companies in this market is based on a percentage of its total market capitalization.

6. After listing, the company must submit quarterly, half-yearly and annual accounts to the exchange.

7. At the time of listing, the number of shareholders in the company must not be less than 300; and

8. The securities must be fully paid at the time of allocation. (p 46).

A benefit that accrues to members of the first tier markets is that the amount of money that the firm can raise in the market is unlimited. This however depends on the borrowing capacity of the company.

\section{Second tier securities market}

The second tier securities market (SSM) as asserted by Akpan (2004) was introduced on 30th April, 1985, primarily to attend to the needs of small and medium size enterprises, which cannot meet the strict listing requirements of the first tier market. In effect, it provides an 
avenue for smaller companies to access public issues for expansion. The first company to raise capital from this segment of the second tier market was Juli Pharmacy and the number of companies covered by the scheme has grown from zero in 1985 to 16 in 2003.

The listing requirements according to Akpan (2004) in this market include:

1. That at least 10 percent of the nominal share capital must be offered to the public.

2. At the point of listing the number of shareholders must not be less than 100;

3. The quotation fee for companies in this market is a flat rate of N30,000 per annum;

4. The amount that can be raised may not exceed N100 million.

These operators include Brokers/Dealers, Issuing Houses, Registrars, Underwriters, Trustees and Portfolio/fund managers, which provide various services for the investors and borrowers in the capital market.

\section{Stockbrokers / dealers}

According to Asika (2004) a stockbroker is a licensed member of the stock exchange, who has the responsibility of maintaining a fair and orderly succession of prices for a specific securities traded on the exchange. They, among others functions, act as agents for the public, receiving and executing buy or sell orders for share according to the instructions of their clients. Mbat (2001) noted that the stock brokerage firm is a limited liability company, a facilitator and one of the principal agents of the stock exchange. It is a dealing member and acts as an intermediary. It is licensed to represent and trade in securities on the market on behalf of investors for a commission, i.e. brokerage fee. The; Nigerian Stock Exchange (NSE) regulates the activities of the brokers/dealers. Since the tight coupling of the Automated Trading System (ATS) and the central securities clearing system (CSCS) servers in 2000, the stock brokerage firms are responsible for the allotment of traded shares in the system and are also involved in the trading of unlisted securities.

Stockbrokerages also provided advisory services by giving professional advice on choice and management of investments and assisting project sponsors raise funds. Basically, they trade in secondary market.

\section{Issuing houses}

An issuing house as asserted by Adetunji (1997) is a financial institution, a non dealing member of the NSE that prepares prospectus to sell new securities offered to the public by companies and governments. In addition to preparing and managing issues, it underwrites and advises on pricing for successful floatation. Since it handles new issues of securities, it is primary market intermediary of the Nigerian capital market (NCM). The activities of an issuing house according to Adetunji (1997) cover: offers for subscription, right issues, offers for sale, private placements, etc. They also serve as financial advisers and coordinators of capital rising exercise on mergers, acquisitions and takeovers. The stipulated minimum paid-up capital of an issuing house is N40 million. Applications to raise funds in the capital market pass through issuing houses. Generally, issuers of securities have a period of three months after SEC approves an issue for the completion of the process. The incorporation of the Central Securities Clearing System (CSCS) has benefited the activities of issuing houses. Prior to it, cancellation and frequent re-issuance of certificates complicated stock market delivery and settlement processes. The CSCS coupled with the e-business platform and internet portal has, in addition, impacted positively by enhancing corporate visibility, affording real time access to information on transaction in company securities and online access to general information on market activities. 


\section{The Nigerian stock exchange (NSE)}

The NSE is a self-regulatory organization and supervises the operations of the format capital market. It provides a mechanism for mobilizing private and public savings, and making them available for productive purposes. Moot (2001) opine that the NSE provides a means for trading in new and existing securities and encourages enterprises of different scales to gain access to public listing. It also regulates the market and protects the investors. It operates the main exchange for relatively large enterprises and the Second Tier Securities Market (SSM) for small and medium scale enterprises. Since inception, the securities listed have grown from 18 in 1986 to nearly 460 in 2006 consisting of government stocks. Bonds, industrial loans (debenture) preference stocks and Equity/Ordinary Shares of companies.

According to Nzota (2004) the stock exchange is a membership institution, with 296 dealing and non-dealing members as at end 2004. The dealing members are stockbrokerage firms, while the non-dealing members are issuing houses, registrars etc as well as individuals who are distinguished in capital market activities. The NSE is governed by a council, which is presided over by a president. The members of the council are elected at the NSE's Annual General Meeting. The functions of the council include the following; granting of the quotation and listing of securities; formulating rules and regulations for the stock market; enforcement of discipline among members of the Exchange, dealing with complaints about and amongst brokers and the investors, and protecting of investors interest.

Akpan (2004) noticed that the exchange witnessed tremendous growth since inception with the Lagos Stock Exchange (LSE) alone having about three million individual investors and hundreds of institutional investors, including foreign based companies that constituted approximately 47 percent of the quoted companies. As at 2002, 7 branches have been established: Kaduna 1978; Port Harcourt, 1979; Kano, 1989; Onitsha 1990; Ibadan, 1990; Abuja, 1999 and Yola, 2002 with Lagos as the head office. Most of the branches are connected online to the trading engine in Lagos. The exchange trades via the Automated Trading System (ATS), which replaced the call over system in April 1999. Prices of new issues are determined by issuing houses / stockbrokers, while on the secondary market, stockbrokers determine the prices through their bids/quotations. The market / quoted prices, along with All-share Index, are published daily. Clearing, settlement and delivery of transactions on the NSE are done electronically through the Central Securities Clearing System (CSCS), a subsidiary of the exchange. The CSCS limited also referred to as the "Clearing House" was Incorporated in 1997, as part of the effort to make the Nigerian stock market efficient and investor friendly. In addition to clearing, settlement and delivery, the CSCS offers custodian services.

\section{Trustees}

According to Nnanna (2004), with the growth and expansion of the capital market to include unit trust schemes and increased recourse to debt securities by corporate bodies, the trustee assumes more vital roles. A trustee holds and manages assets. Trust or pension funds, and debt securities on behalf of individual or institutional investors. He thus protects their interest by ensuring adherence to the rules governing the instrument. Under the unit trust scheme, the fund manager appoints an independent trustee on behalf of the unit holders as a custodian of the underlying assets of the funds.

\section{Underwriters}

According Ekpenyong (1994) underwriting in the securities market is aimed at facilitating the success of the offer. Thus, the underwriter of a security is an institution that performs some functions that could induce the success of the securities on offers (issues). This is a form of 
hedging against the failure of the securities offered. Therefore, the underwriter at the time of subscription makes a promise to make money available in the event of under subscription. Underwriters know this as a stand. The payment to a stand by underwriter is a commission that is determined at the point of agreement.

Ekineh (2000) noticed that the Nigerian capital market has witnessed very few firms underwriting offers. The major underwriters of public offers are the deposit money banks and insurance companies. Also, a well-developed pension fund has the potential of becoming a veritable source of underwriting public offers.

\section{Regulators in the market}

Edogi (2006) explained that the regulatory bodies of the Nigerian Stock Market consist of the securities and Exchange Commissions, Nigerian Stock Exchange, Central Bank of Nigerian and Federal Ministry of Finance. On the basis of their experiences, different countries evolve different status for stock market operations. In Nigerian, there are several status that have provisions for guiding the operations of the stock market. The statutes are:

1. The Lagos Stock Exchange Act, 1961;

2. Trustee Investment Act, 1962

3. Companies and Allied Matters Decree (CAMD), 1990

4. Banks and Other Financial Institutions Decree, 1991;

5. Nigerian Promotion Investment Decree, 1995;

6. Foreign Exchange (Miscellaneous Provisions Decree, 1995;

7. Securities and Exchange Commission Decree, 1999;

8. Investment and Securities Act, 1999

\section{Securities and exchange commission}

The apex regulatory body in the capital market is the Securities and Exchange Commission (SEC). It empowered by the Securities and Exchange Commission Decree, 1999 amongst others to:

1. Register and approve all securities for subscription or sale to the public, while ensuring that full disclosure is given in the prospectus and other issue documentation in the case of a public offer.

2. Ensure fairly, orderly and equitable dealings in securities.

3. Register commodity and stock exchange, investment advisers and all market operators with a view to maintaining an enviable standard of conduct and professionalism in the stock market.

4. Review, approve and regulate mergers and acquisitions;

5. Perform market oversight functions through surveillance, monitoring and on/off site inspection with a view to assuring fair play and equitable dealings on the Exchange; and

6. Promote investors education and all categories of intermediaries in securities market.

Thus, the SEC regulates the issue of securities and the conduct of operates/players in the market, as well as sales practices. In addition to its administrative and regulatory roles, the SEC is also vested with the power to suspend or revoke the registration of any person/body involved in price manipulations, unjust or inequitable practices, after an opportunity for hearing has been given. The commission may annual such a transaction and further prescribes appropriate measures to rectify such irregularities. The SEC is also expected to relate with some international securities market organizations, stock exchanges, the internationals finance corporate. It became a member of the International Organisation of Securities Commission (IOSCO) in 1985). The commission has also sustained its membership with the Emerging Market Committee (EMC) and the Africa and -Middle East Regional Committee (AMERC), 
among others. The membership provides a platform for SEC to showcase the Commission to the external world, thereby, inducing foreign investment.

\section{Central Bank of Nigeria}

According to Nnanna (2004), the Central Bank of Nigeria is a major player in the capital market. First, it is the apex regulatory authority for both banking and non bank financial institutions. Also, it has underwritten Federal Government debt issues, by absorbing all unsubscribe positions. This it does by laying down terms and conditions for the issuance of Federal Government. Stock, thereby imparting resilience and stability in the market by purchasing all government stocks on issues that are not taken up by other purchasers and then subsequently selling them to the market as the need arises. Besides, the Central Bank of Nigeria participated actively in setting up the development finance institutions, by subscribing to their capital. Because of the important role of an efficient and well, functioning payments system in the transmission of monetary policy, the financial sector become viable, the CBN is also at the forefront in enhancing the payments and settlement system (Nnanna 2004).

\section{CHAPTER THREE RESEARCH METHODOLOGY}

This chapter describes the procedure and strategies employed for data collection for this study. It is the road map to the findings of the proceeding chapters. It focuses on the research design, method of data collection, model specification and method of data analysis

\section{Research design}

Research design denotes the structuring of a study, and strategy of investigation concerned so as to obtain answers to research questions and to control variance (Etuk, 2003). Put another way a research design is the structuring of a study aimed at identifying variables and their relationship to one another. This is used for the purpose of obtaining data to enable the researcher test hypotheses or answer research questions (Asika, 1991).

Arising from the above statements, the study adopts exploratory survey of the performance of the Nigerian Capital market between 1986 and 2005 covering a period of 20years.

\section{Sources of data and method of collection}

Data for the study were generated from secondary sources. The bulk of the data were extracted from the Nigeria Stock Exchange Annual Reports. Daily Nigerian Business Investment lists, list of current capital market operators central Bank of Nigeria Annual Reports, and publications from Security and Exchange Commission Annual Reports and Publications, Federa $\backslash$ Office of Statistics. Collation of data from the internet on Discuss and share ideas with selected investment companies in Nigeria and fact book

\section{Techniques of data analysis}

The data generated from the various publications were summarized and tabulated. The multiple regression model would be used to analysis the data in line with the hypothesis of the study. This technique should bring out whether the Nigerian capital market contributed significantly to economic development of Nigeria or otherwise

\section{Model specification}

Based on our purpose of the study, and the statement of our problem, it was observed that Economy (GDP), Market capitalization, value of stocks, value index of equities and listed securities aided in capital market performances. A model for capital market performance is built in line with the hypothesis to help analyze the study better as shown below: 


\begin{tabular}{|c|c|c|}
\hline $\begin{array}{l}\text { GDP = a } \\
\text { Where: }\end{array}$ & & ts + Vide + Lsts + r \\
\hline GDP & $=$ & the economy \\
\hline $\mathrm{a}$ & $=$ & constant \\
\hline Mkcap & $=$ & market capitalisation \\
\hline Vsts & $=$ & value of stocks \\
\hline Vide & $=$ & value index of equities \\
\hline Lsts & $=$ & Listed securities \\
\hline $\mathrm{r}$ & $=$ & error estimate \\
\hline
\end{tabular}

\section{Estimation and validation}

The ordinary least squares will be our estimated technique. The OLS is used to estimate the models because it exhibits the characteristics of the best linear unbiased estimator. It also expected to have a minimum variance. The validation of our estimated parameters will be conducted based on three criteria. These include:

Economic (a priori) criterion: the coefficients of the parameters estimated shall be validated on theoretical a priori criteria. That is the sign and sizes of magnitudes of the estimated parameters will be judged based on what economic says should be their sign and magnitudes.

Although in some cases, their sign and magnitude are not clear as predicted by the econometric a priori theoretical expectation. In these cases, we are going to make use of previous studies in this area.

Our economic a priori expectation, as previously stated indicate the signs that should characterize the parameters to be able to make negative impact on the endogenous variable.

Statistical criteria: The Statistical criteria are more or less an outcome of the estimated parameters of the equations. Among which include the correlation coefficient of the adjusted (R2), standard error (SR), and standard deviation of the estimates, student's t-test and fstatistics. It should be noted that the R2 gives us the insight or measure of the extent or degree to which the explanatory variable are responsible for the change in the dependent variables (endogenous variable).

The standard deviation, as the name implies measures the rate of dispersion of the estimates around the true parameters because the higher the standard deviation (standard error) of the parameter, the less reliable it is, and vise versa.

The t-test is an offshoot of the standard error test. The t-test estimates the sample value of the $t$ by determining the critical region in a two tail test $n-k$ degree of freedom. If our t-falls into the critical region we reject the null hypothesis, otherwise we accept.

F-test is employed for joint test of significant of the estimates in the equation. We also compare the observed $\mathrm{F}$ ratio with the theoretical value at 5 percent level from F-table where VI = K-l and V2 $=\mathrm{N}-\mathrm{K}$ degree of freedom, where $\mathrm{k}$ is the number of estimated parameters, $\mathrm{n}$ is the sample size Here, the theoretical value of $\mathrm{F}$ defines the critical region of the test at these levels of significance. If Ho calculated is greater than the table value of Ho, we reject our null hypothesis and draw a conclusion in favour of our $\mathrm{H} 1$. 
Econometric criteria: We made use of economic criteria (second order test). Economic criteria determine the reliability of the first order test and the standard errors of the estimates. These help us to determine whether our estimates have the desirable properties of best linear unbiased estimates (BLUE). We firstly assumed that there is no autocorrelation or serial correlation of the random variables. If this is violated, the standard errors of the parameters cease to be useful criteria for the valuation of the statistical significance of the coefficient. To test the validity of the assumption of non auto correlated disturbances, we compute the Durbin Watson statistics.

In the Durbin Watson test, we compare the empirical d; value calculated from the regression residuals with the $d$, and du in the Durbin Watson table and with their transformation 4-d) and (4-du). If $d<d i$, we reject the null hypothesis of the no auto correlation and accept that there is a positive auto-correlation of the first order.

If $d u<d(4-d u)$, we accept the null hypothesis of no auto-correlation and if $d<d u$ or if 4 -du $<4$ $\mathrm{d} 1$, the test is inconclusive.

\section{CHAPTER FOUR DATA PRESENTATION ANALYSIS AND DISCUSSION OF FINDINGS \\ Data presentation}

In this chapter, data collection with respect to the performance of the Nigerian stock market are presented, analyzed and interpreted in order to have informed judgment about the level of performance in the stock exchange.

The data relevant to the study are presented in tables. They are mainly secondary data sourced from the Central Bank of Nigeria (CBN) Statistical Bulletin Nigerian Stock Exchange Annual Reports and publications others are from securities and exchange commission annual reports and publications, Federal office of statistics reports and publication, World Bank publications, Federal Ministry of Finance panel on Review of the Nigerian capital market covering a period of twenty (20) years (1986 2005). The data generated are presented in the following tables a review of the performance of the Nigerian Capital market statistically reveals in Table 4.1 shows the relationship between market capitalization and various stocks performances in the market. The market capitalization was increasing progressively for the twenty years under review. 1986 to 1987 recorded an increase of $25.02 \%$ while 1988 to 1999 stood at 35.84 0k. From 2001 to 2006 the market capitalization recorded a percentage increase of 10.194, 8.67757, 12.3315, 2.71891, and 7.2353 respectively. Government stocks recorded a decrease from 1986 to 1998 picked up from 1999 to 2000, then fall again in 2001 and maintained an increase in 2000 to 2005 with a percentage change which stood at 11.12195, 66.1716, 1.38696, $53.8227,7.6512$, and 0.06596 respectively. Industrial stocks had a noticeable increases of 1.96078, 8.10811, 15.2672, 7.74648, 7.18954, 12.069, 1.69492, 2.20994, 1.0929, 0.549451, $2.15054,5.10204,0.51282,0.75441,0.51282,68.53,3.154 .31,1.48$ and 0.515464 respectively from 1986-2005. Equity recorded a differential percentage increases of 95.5976, 8.92808, 21.886.3565.34, 11.71 respectively. From 2000 to 2005 there was a tremendous increase in equity traded in the Nigerian stock exchange. While market capitalization picked up from 1996 to the present date. Government stocks and industrial stocks needed to be encouraged by revisiting of its trading policy for the public interest.

Table 4.2 shows the influence of capital market performance on the economy. The economy, represented by the Gross Domestic Products (GDP); shows an increase of 36.35, 79.56, 35.84, 63.37, 225.80, 146.18, 215.01, 1,049.69, 788.77, 85.55, -69.34, 428.00, 1,648.52, 645.80, $192.09,644.821,601.00,974.20$, and 220.00 respectively from 1986-2005. 
TABLE 4.1: The relationship between market capitalization and stocks performances

\begin{tabular}{|l|l|l|l|l|l|l|l|l|}
\hline Years & $\begin{array}{c}\text { Marker } \\
\text { capitalization }\end{array}$ & $\begin{array}{c}\text { \% } \\
\text { Change }\end{array}$ & $\begin{array}{c}\text { Govt. } \\
\text { stocks }\end{array}$ & $\begin{array}{c}\text { \% } \\
\text { Change }\end{array}$ & $\begin{array}{c}\text { Industrial } \\
\text { stock }\end{array}$ & $\begin{array}{c}\% \\
\text { Change }\end{array}$ & Equities & change \\
\hline 1986 & 108.89 & 25.0275 & 54 & 5.882353 & 100 & 1.96078 & 185 & 1.59574 \\
\hline 1987 & 145.24 & 35.3915 & 51 & 8.510638 & 102 & 8.10811 & 188 & 5.05051 \\
\hline 1988 & 224.8 & 13.7508 & 47 & 9.302326 & 111 & 15.2672 & 198 & 8.75576 \\
\hline 1989 & 260.64 & 19.558 & 43 & 7.5 & 131 & 7.74648 & 217 & 9.20502 \\
\hline 1990 & 324.01 & 41.0687 & 40 & 53.2567 & 142 & 7.18954 & 239 & 4.78088 \\
\hline 1991 & 549.81 & 21.0032 & 26.1 & 18.4375 & 153 & 12.069 & 251 & 7.72059 \\
\hline 1992 & 695.99 & 23.6015 & 32 & 9.965636 & 174 & 1.69492 & 272 & 1.44928 \\
\hline 1993 & 911 & 53.5368 & 29.1 & 3.558719 & 177 & 2.20994 & 276 & 0 \\
\hline 1994 & 1960.69 & 28.6882 & 28.1 & 16.59751 & 181 & 1.0929 & 276 & 0 \\
\hline 1995 & 2749.46 & 3.01763 & 24.1 & 9.049774 & 183 & 0.549451 & 276 & 0 \\
\hline 1996 & 2835.01 & 2.50718 & 22.1 & 15.70681 & 182 & 2.15054 & 276 & 4.545455 \\
\hline 1997 & 2765.67 & 13.4015 & 19.1 & 26.49007 & 186 & 5.10204 & 264 & 0 \\
\hline 1998 & 3193.67 & 34.0449 & 15.1 & 88.2031 & 196 & 0.512821 & 264 & 1.538462 \\
\hline 1999 & 4842.19 & 11.7675 & 128 & 12.37928 & 195 & 0.515464 & 260 & 10.6529 \\
\hline 2000 & 5487.99 & 3.38182 & 113.9 & 11.12195 & 194 & 0.51282 & 291 & 95.5976 \\
\hline 2001 & 5680.08 & 10.1949 & 102.5 & 66.1716 & 195 & 68.5179 & 6610 & 8.92808 \\
\hline 2002 & 6324.9 & 8.67757 & 303 & 0.06596 & 619.4 & 3.147377 & 7258 & 21.8814 \\
\hline 2003 & 6925.9 & 12.3315 & 303.2 & 53.8227 & 600.5 & 4.30279 & 9291 & 635.1056 \\
\hline 2004 & 7900.1 & 2.71891 & 656.6 & 7.6512 & 627.5 & 1.487951 & 1263.9 & 65.3631 \\
\hline 2005 & 8120.9 & 7.2353 & 711 & 1.38696 & 618.3 & 0.75441 & 3649 & 11.79534 \\
\hline
\end{tabular}

Source: CBN Annual Reports and Statement of Accounts 2002-2005

$G D P=G s K+I s k+$ Eties $+r$

TABLE 4.2: Capital market performance on the economy

\begin{tabular}{|l|l|l|l|l|l|}
\hline Years & \multicolumn{1}{|c|}{ GDP } & $\begin{array}{c}\text { Market } \\
\text { capitalization }\end{array}$ & $\begin{array}{c}\text { Volume of } \\
\text { stocks }\end{array}$ & $\begin{array}{l}\text { Value index of } \\
\text { equities }\end{array}$ & Listed securities \\
\hline 1986 & 108.89 & 60.04 & 35.15 & 40.11 & 30.0 \\
\hline 1987 & 145.24 & 69.38 & 39.13 & 40.11 & 30.30 \\
\hline 1988 & 224.80 & 99.98 & 40.0 & 51.99 & 60.70 \\
\hline 1989 & 260.64 & 120.20 & 40.15 & 50.08 & 77.12 \\
\hline 1990 & 324.01 & 244.02 & 40.15 & 51.12 & 80.15 \\
\hline 1991 & 549.81 & 350.0 & 42.15 & 100.0 & 82.11 \\
\hline 1992 & 695.99 & 396.89 & 48.17 & 101.15 & 86.90 \\
\hline 1993 & 911.0 & 519.02 & 48.17 & 138.11 & 90.0 \\
\hline 1994 & $1,960.69$ & 660.60 & 50.0 & 138.11 & 92.30 \\
\hline 1995 & $2,749.46$ & 951.60 & 50.0 & 140.0 & 98.20 \\
\hline 1996 & $2,835.01$ & 966.16 & 50.12 & 100.0 & 99.80 \\
\hline 1997 & $2,765.67$ & 996.58 & 50.12 & 100.0 & 99.90 \\
\hline 1998 & $3,193.67$ & 1861.6 & 50.12 & 300.0 & 99.90 \\
\hline 1999 & $4,842.19$ & $2,721.9$ & 55.5 & 311.10 & 202.09 \\
\hline 2000 & $5,487.99$ & $3,681.10$ & 59.4 & 107.0 & 219.07 \\
\hline 2001 & $5,680.08$ & $3,573.60$ & 59.4 & 107.0 & 258.05 \\
\hline 2002 & $6,324.90$ & $3,734.90$ & 120.4 & 165.80 & 265.03 \\
\hline 2003 & $6,925.90$ & $3,925.90$ & 225.8 & 118.50 & 277.01 \\
\hline 2004 & $7,900.10$ & $5,000.01$ & 262.9 & 100.0 & 288.0 \\
\hline 2005 & $8,120.90$ & $5,120.90$ & 470.3 & 138.50 & 288.0 \\
\hline
\end{tabular}

Sources: International Journal of Business studies, 2000. CBN Annual Report and Statement of Accounts for 2001-2006.

GDP $=$ Mk+cap + Vsts + Vide + Lsts $+r$

The growth of the economy was not steady as revealed in the analysis. Market capitalization was noticed to pick up from 1998 to 2005 with the following differential increases of 860.30, $959.20,-107.50,161.30,191.00,1,674.11$ and 120.89 . Value of stocks record a little increases 
of 3.98, 0.87, 0.15, 0.00, 2.00, 6.02, 0.00, 1.83, 8.00, 0.12, 0.00, 0.00, 5.38, 3.90, 0.00, 61.00, $105.40,37.10$, and 207.40 from 1986-2005.

Value index of equities was not stable as it rises and falls, the table revealed that early 1990, 1993, 1995, 1998-1999 and 2005 maintained a reasonable figures of 138.50 respectively. The listed securities in the capital market keeps on a little steady increases from 1986 to 1997. An improved increase of $102.19,16.98,38.98,6.98,11.98$ and 10.99 was noticed from the year 1999 to 2005.

Table 4.3 revealed the relationship between capital market performance and stock traded. The table revealed a steady growth differential of 2.10, 1.00, 3.00, 11.90, 5.60, 14.40 and 17.60 for 1986 to 1993 . While 1994 to 2005 stood at 106.60, 114.50, 6.40, -28.70, - 63.40, 42.80 and 7.20 respectively. The vas (Volume of Stock) recorded a rise from 1986 to 1991, failed 1992 to 1993; and gotten a steady figures of $49,560,000$ to $49,515,000$ respectively. A tremendous growth was recorded from 1996 to 2005.

TABLE 4.3: Market performance and stock traded

\begin{tabular}{|l|c|c|c|c|}
\hline Years & MPS(N) & VOS $m)$ & VAS (Nm) & LNR\% \\
\hline 1986 & 8.9 & 20525 & 382.4 & 14.0 \\
\hline 1987 & 11.0 & 21560 & 850.3 & 25.3 \\
\hline 1988 & 12.0 & 33444 & 610.3 & 26.0 \\
\hline 1989 & 15.0 & 39270 & 225.4 & 20.2 \\
\hline 1990 & 26.9 & 41770 & 242.1 & 31.2 \\
\hline 1991 & 32.5 & 49029 & 491.7 & 36.1 \\
\hline 1992 & 46.9 & 40398 & 804.4 & 20.2 \\
\hline 1993 & 64.5 & 42074 & 985.9 & 20.2 \\
\hline 1994 & 171.1 & 49564 & 1838.8 & 18.4 \\
\hline 1995 & 285.6 & 49515 & 6979.6 & 18.3 \\
\hline 1996 & 292.0 & 78089 & 10330.5 & 22.5 \\
\hline 1998 & 263.3 & 84935 & 13571.1 & 21.3 \\
\hline 1999 & 199.9 & 123508 & 14072.0 & 26.0 \\
\hline 2000 & 175.6 & 256523 & 28153.1 & 20.6 \\
\hline 2001 & 662.9 & 426163 & 57683.8 & 19.6 \\
\hline 2002 & 763.9 & 451850 & 59406.7 & 19.5 \\
\hline 2003 & 795.3 & 621717 & 120402.6 & 17.8 \\
\hline 2004 & 1356.6 & 973526 & 225820.0 & 17.3 \\
\hline 2005 & 1399.4 & 1021966 & 262935.8 & \\
\hline
\end{tabular}

Sources: World Bank and Nigerian Stock Exchange CBN Facts Book

$P S=V O S+V A S+L N R$

$M P s=a+v a s+V A S+L N R$

$M P s=a+b 1 V O S+b 2 V A S+b 3 L N R+j$

2005 recorded the greatest differential increase of 3.003, 113.00 naira. The VAS (Value of Stocks) stood at 382.859.3, 610.3, 225.4, 242.1, 491.7, 804.4, 985.0, 1,838.8, and 6,979.6 for the year 1986 to 1995.1996 to 2005 recorded 10,330.5, 13,571.1, 14,072.0, 28,153.1, 57,683.8, 58,406.7, 120,402.6, 225,820.0, 262,935.8, and 454,262 and 839.33. It shows a great improvement in the capital market, due to policies and programme in the stock exchange market. The LNR rate stood at a rise and fall rate of $14.018 .3,25.5,26.0,20.2,31.2,36.120 .2$, 19.6, 19.5, 17.8 and 17.3 presents for the year 1987 to 2006. The unsteadiness of the LNR was due to the prices of demand and supply of stocks traded in the capital market that implies a stormy relationship in the consideration of the various variables under review.

Table 4.5 revealed the Nigerian stock exchange all share price index, covering the month by month and values from 1986 to 2005, December, 31st. The table 4.4 revealed a great 
improvement in the Nigerian stock exchanges all price index in January of 1986 to 2005 with the index positions of 168.90, 190.80, 239.00, 343.00, 528.70, 794.00, 1,113.40, 1,666.30, 2,285.33, 5,135.07, 7,668.28, 6,435.53, 5,495.00, 5752.90, 9,54.39, 1,031.95, 1,3210.11, 22,712.26, 22,775.10, and 23,679.40. While in December, 1986 to 2005 all index stood at 190.90, 233.6, 325.30, 513.80, 783.00, 1,107.60, 1,543.80, 2,205, 5,092.00, 6,992.00, 6,440.51, $5,672.70,5,266.40,8,11.00,10,693.10,10,663.10,19,942.84,23,844.9,24,085.76$ and $33,189.30$. in comparing the all share price index of $161.17,210.75,273.81,465.55,671.45$, 930.88, 1,229.68, 17,144.16, 364,422.75, 5,481.46, 7,838.58, 5,960.16, 5,225.87, 6,090.93, $10,390.38,9,634.02,15,639.14,25,005.10,22,866.43$ and 28,101.58 for the year 1986 to 2005. The analyzed means introduction of new shares in the capital market, that such increases bring growth and development of the Nigerian capital market. It also means that Nigerian companies are utilizing the capital market functions and investors and the general public are now investing in Nigeria companies. The performances are also encoining and attracting foreign investor.

Table 4.6 revealed the aggregate financial indicator for listed companies in the Nigerian capital market. The financial indicators identified in the table are the turnover, profit before tax, and profit after tax, total dividend, average earning per share, and average dividend per share. The turnover was in the increase of $1,605.60,1,308.80,-2,392.90,1,181.60,317.00,1,161.50$, 2,093.50, 4,350.80, 8757.70, 9,127.10, 9,127.20, 17,934.40, 37,309.90, 56,773.60, 100, 245.40, $30,946.90,87,821.80,125,908.20,81,175.30,69,391.30,91,664.60,93,706.70,90,271.20$, $283,400.00,1,131,345.00$ and $-425,250.00$ from 1986-2006. The turnover was greatly encouraging while from 2003 to 2004 brought a sharp draw of $-425,250.00$. Profit before tax rises from 637.9 to 33,946.0 in the year 1979 to 1994 and show to 32,098.0 in, 1995. The profit before tax picked up again to 34,034.5 to 110,890.0 in the year 1996 to 2004 under reviewed. Meaning a favourable growth, and development in the operations of quoted companies in Nigeria.

TABLE 4.4: Data used for regression analysis (1986-2005)

\begin{tabular}{|l|l|l|l|l|}
\hline \multicolumn{1}{|c|}{ Years } & \multicolumn{1}{|c|}{$\begin{array}{c}\text { (Market } \\
\text { capitalization) GDP }\end{array}$} & & VAS (Nm) & LNR\% \\
\hline 1986 & 71194.9 & 20525 & 382.4 & 14.0 \\
\hline 1987 & 77733.2 & 21560 & 850.3 & 16.3 \\
\hline 1988 & 83179.0 & 33444 & 610.3 & 25.5 \\
\hline 1989 & 92238.5 & 39270 & 225.4 & 26.0 \\
\hline 1990 & 94236.3 & 41770 & 242.1 & 20.2 \\
\hline 1991 & 97019.9 & 42074 & 491.7 & 31.2 \\
\hline 1992 & 99604.2 & 49029 & 804.4 & 36.1 \\
\hline 1993 & 100936.7 & 40398 & 985.9 & 20.2 \\
\hline 1994 & $103,078.6$ & 42074 & 1838.8 & 20.2 \\
\hline 1995 & $104,600.6$ & 49564 & 6979.6 & 20.4 \\
\hline 1996 & $109,972.6$ & 78089 & 10330.5 & 18.4 \\
\hline 1997 & $113,509.0$ & 84935 & 13571.1 & 18.3 \\
\hline 1998 & $116,655.6$ & 123509 & 14072.0 & 22.5 \\
\hline 1999 & $121,207.8$ & 256523 & 28153.1 & 21.3 \\
\hline 2000 & $126,323.8$ & 426163 & 51683.8 & 26.0 \\
\hline 2001 & $131,489.8$ & 451850 & 59406.7 & 20.6 \\
\hline 2002 & $136,470.0$ & 621717 & 120402.6 & 19.6 \\
\hline 2003 & $139,653.2$ & 973526 & 225820.0 & 19.5 \\
\hline 2004 & $141,616.8$ & 10121966 & 262935.8 & 17.8 \\
\hline 2005 & $143,200.6$ & 4025076 & 454262839.3 & 17.3 \\
\hline
\end{tabular}

Sources: (i) CBN statistical bulletin Vol. 172006

(ii) Securities and Exchange Commission 


$\begin{array}{llll}V & = & f(X 1 X 2 X 3) & \text { (i) } \\ G D P & = & f(V O S, V A S, L N R) \_ \text {(ii) }\end{array}$

TABLE 4.5: The Nigerian stock exchange all-share index (month end values (1986-2005))

\begin{tabular}{|c|c|c|c|c|c|c|c|c|c|c|c|}
\hline YEAR & 1986 & 1987 & 1988 & 1989 & 1990 & 1991 & 1992 & 1993 & 1994 & 1995 & 1996 \\
MONTH & 1 & 2 & 3 & 4 & 5 & 6 & 7 & 8 & 9 & 10 & 11 \\
\hline Jan & 168.90 & 190.80 & 239.00 & 343.00 & 528.70 & 794.00 & 1113.40 & 1666.30 & 2285.33 & 5135.07 & 7668.28 \\
\hline Feb & 166.20 & 191.40 & 251.00 & 349.30 & 557.00 & 810.70 & 1119.90 & 1715.30 & 2319.77 & 5182.36 & 7699.28 \\
\hline Mar & 161.70 & 195.50 & 256.90 & 356.00 & 601.00 & 839.10 & 1131.10 & 1792.80 & 2551.13 & 5266.20 & 8561.38 \\
\hline Apr & 157.50 & 200.10 & 257.50 & 362.00 & 625.00 & 844.00 & 1147.30 & 1845.80 & 2785.43 & 5412.35 & 8729.79 \\
\hline May & 154.20 & 199.20 & 257.10 & 382.30 & 649.00 & 860.50 & 1186.20 & 1875.50 & 3100.79 & 5724.12 & 8592.32 \\
\hline June & 196.10 & 206.00 & 259.20 & 417.40 & 651.80 & 870.80 & 1187.50 & 1956.10 & 3596.17 & 5798.72 & 8459.29 \\
\hline July & 193.40 & 211.50 & 269.20 & 445.40 & 688.00 & 879.70 & 1188.80 & 1926.30 & 4314.27 & 5919.43 & 8148.80 \\
\hline Aug. & 193.00 & 217.60 & 281.00 & 463.60 & 712.10 & 969.30 & 1195.50 & 1914.10 & 4664.61 & 6140.95 & 7681.99 \\
\hline Sept & 194.90 & 224.00 & 279.90 & 468.20 & 737.30 & 1022.00 & 1217.30 & 1956.00 & 4858.06 & 6521.88 & 7130.79 \\
\hline Oct. & 154.80 & 218.50 & 298.50 & 480.30 & 757.50 & 1076.90 & 1310.90 & 2023.40 & 5068.01 & 6634.78 & 6554.77 \\
\hline Nov. & 193.40 & 231.40 & 311.20 & 502.60 & 769.00 & 1098.00 & 1414.50 & 2119.33 & 5095.16 & 6775.62 & 6395.76 \\
\hline Dec. & 190.90 & 233.60 & 325.30 & 513.80 & 783.00 & 1107.60 & 1543.80 & 2205.00 & 5092.00 & 6992.00 & 6440.51 \\
\hline
\end{tabular}

\begin{tabular}{|l|c|c|c|c|c|c|c|c|c|}
\hline YEAR & 1997 & 1998 & 1999 & 2000 & 2001 & 2002 & 2003 & 2004 & 2005 \\
MONTH & 12 & 13 & 14 & 15 & 16 & 17 & 18 & 20 \\
\hline Jan & 6435.62 & 5495.00 & 5752.90 & 9542.39 & 11031.95 & 13210.11 & 22712.28 & 22775.10 & 23679.4 \\
\hline Feb & 6426.17 & 5376.50 & 5955.73 & 9180.53 & 10644.75 & 13623.36 & 25169.29 & 21953.50 & 23843.0 \\
\hline Mar & 6298.50 & 5456.20 & 5966.24 & 954475 & 9544.75 & 13762.50 & 22965.97 & 20682.40 & 23336.6 \\
\hline Apr & 6113.90 & 5336.50 & 5892.79 & 9591.58 & 9591.58 & 13390.09 & 26205.20 & 21961.70 & 23301.2 \\
\hline May & 6033.90 & 4916.20 & 6095.35 & 10189.24 & 10189.24 & 14002.21 & 27.505 .64 & 21862.80 & 24745.7 \\
\hline June & 5892.08 & 4916.20 & 6466.72 & 11094.33 & 11094.33 & 14537.80 & 290.98 .89 & 21364.80 & 26316.2 \\
\hline July & 5817.03 & 5977.30 & 6900.73 & 10861.11 & 10861.11 & 13992.86 & 27.062 .13 & 21911.00 & 27880.5 \\
\hline Aug. & 5795.17 & 4964.30 & 7394.05 & 10529.62 & 10529.62 & 15813.07 & 25.07612 & 22935.40 & 33096.4 \\
\hline Sept & 5697.67 & 4840.20 & 7298.88 & 10594.99 & 10594.99 & 16252.67 & 22739.68 & 24635.90 & 32554.6 \\
\hline Oct. & 5671.00 & 5032.50 & 7415.34 & 11339.61 & 11339.61 & 18.874 .12 & 23526.13 & 25873.80 & 32643.7 \\
\hline Nov. & 5688.19 & 5133.20 & 7141.43 & 11253.31 & 11253.31 & 20.268 .15 & 24155.43 & 24355.00 & 32632.5 \\
\hline Dec. & 5672.70 & 5266.40 & 811.00 & 10693.10 & 10963.10 & 19942.84 & 23844.45 & 24085.76 & 33189.3 \\
\hline
\end{tabular}

Source: www.sec.gov.ng

TABLE 4.6: Aggregate financial indicators for listed companies

\begin{tabular}{|l|l|l|l|l|}
\hline Years & \multicolumn{1}{|c|}{$\begin{array}{c}\text { Turnover } \\
\text { N million }\end{array}$} & \multicolumn{1}{c|}{$\begin{array}{c}\text { Profit } \\
\text { Before tax } \\
\text { m }\end{array}$} & Profit after Nm & Total Dividend \#m \\
\hline 1986 & $9,794.4$ & $1,291.3$ & 837.5 & 351.4 \\
\hline 1987 & $11,887.9$ & $1,421.7$ & 914.9 & 463.1 \\
\hline 1988 & $16,238.7$ & $1,772.4$ & $1,076.4$ & 562.5 \\
\hline 1989 & $24,996.4$ & $2,514.2$ & $1,784.9$ & 872.5 \\
\hline 1990 & $34,123.5$ & $3,044.7$ & $1,996.9$ & $1,081.8$ \\
\hline 1991 & $43,250.7$ & $3,575.2$ & $2,209.0$ & $1,290.8$ \\
\hline 1992 & $61,185.1$ & $6,427.4$ & $4,586.6$ & $1,701.8$ \\
\hline 1993 & $98,495.0$ & $18,788.1$ & $9,130.8$ & $3,427.1$ \\
\hline 1994 & $155,268.6$ & $28,005.9$ & $18,842.3$ & $8,437.7$ \\
\hline 1995 & $255,514.0$ & $33,946.0$ & $23,027.0$ & $9,726.1$ \\
\hline 1996 & $286,460.9$ & $32,098.9$ & $25,200.9$ & $9,857.4$ \\
\hline 1997 & $374,282.7$ & $34,034.5$ & $25,289.6$ & $10,465.4$ \\
\hline 1998 & $500,190.9$ & $46,101.4$ & $34,445.4$ & $10,923.6$ \\
\hline 1999 & $581,366.2$ & $51,841.9$ & $40,871.1$ & $11,185.0$ \\
\hline 2000 & $650,755.5$ & $63,941.8$ & $52,891.1$ & $11,621.1$ \\
\hline 2001 & $742,422.1$ & $81,922.8$ & $53,574.4$ & $28,942.4$ \\
\hline 2002 & $838,128.8$ & $101,026.3$ & $72,782.3$ & $36,619.2$ \\
\hline 2003 & $926,400.00$ & $108,400.0$ & $74,000.0$ & $36,818.9$ \\
\hline 2004 & $1,209,800.0$ & $126,900.0$ & $85,500.0$ & $42,112.1$ \\
\hline 2005 & $784,550.0$ & $110,890.0$ & $85,880.0$ & $47,405.3$ \\
\hline
\end{tabular}

Sources: Securities and Exchange Commission 
The various listed companies do not record any losses as indicated in the table. Profit after taxes increases from 837.5 to $1996.9 \mathrm{~m}$ in 1986to 1987. 1991 to 1995 recorded increase of $20818 \mathrm{~m}$. A tremendous improvement was achieved in the year 1996 to 2005 with profit after tax of $25200.9 \mathrm{~m}$ to $85,880.0 \mathrm{~m}$ respectively. The table revealed that listed companies declared total dividend of 351.4 to $463.1,562.5,351.4,463.1,562.5$ and $872.7 \mathrm{~m}$ in the years between, 1986 to 1995 respectively. 1996 to 1996 stood at 1,081.8m 1,290.8m, 1,701.8m, 3,427.1, 8,437.7m, 9,726.1, and 9,857.4 respectively. From 1997 to 2005 recorded the greater total dividend declination of $10,465.4 \mathrm{~m}, 10,923.6 \mathrm{~m}, 11,185.0 \mathrm{~m}, 11,621.1,28,942.4,112.1 \mathrm{~m}$, and $47,405.3 \mathrm{~m}$ respectively. Average earning per share stood at $0.18,0.20$, from 1980,1981 , while 1982 ad 1983 stood at 0.18 and 0.19 for 1984 . 0.26 was for 1985 and 1986 respectively. 1987 to 2005 stood at $0.28,0.29,0.36,0.30,0.28,0.50,0.68,1.05,1.01,0.99,1.52,1.42,1.54,1.98$, $1.89,1.78,1.28,1.47$ and 1.66 respectively. The average dividend per share for 1980 to 1981 stood at 0.10 respectively, while 1984 stood at 0.09 .1985 and 1986 recorded 0.11 .1987 to 2005 recorded average dividend per share of $0.14,0.15,0.18,0.16,0.17,0.19,0.24,0.47,0.40$, $0.39,0.65,0.48,0.47,0.53,0.81,0.78,0.72,0.75$ and 0.77 respectively.

TABLE 4.7: Performance of equities listed in the Nigeria stock exchange

\begin{tabular}{|c|c|c|c|}
\hline Years & $\begin{array}{c}\text { Trading volume } \\
\text { (Amillion) }\end{array}$ & $\begin{array}{c}\text { Trading value } \\
(\mathbf{A m})\end{array}$ & Turnover ratio \\
\hline 1986 & 19.2 & 22.0 & 0.6 \\
\hline 1987 & 23.5 & 27.2 & 0.7 \\
\hline 1988 & 18.8 & 22.4 & 0.4 \\
\hline 1989 & 19.5 & 22.9 & 0.3 \\
\hline 1990 & 52.6 & 87.8 & 0.7 \\
\hline 1991 & 47.2 & 90.0 & 0.5 \\
\hline 1992 & 105.7 & 237.1 & 0.9 \\
\hline 1993 & 186.7 & 286.6 & 0.7 \\
\hline 1994 & 190.8 & 401.3 & 0.7 \\
\hline 1995 & 346.1 & $1,788.1$ & 1 \\
\hline 1996 & 733.5 & $6,923.2$ & 2.5 \\
\hline 1997 & $1,160.0$ & $10,923.2$ & 3.9 \\
\hline 1998 & $2,080.6$ & $13,555.3$ & 5.1 \\
\hline 1999 & $3,913.6$ & $14,026.6$ & 4.8 \\
\hline 2000 & $4,998.1$ & $28,146.5$ & 6 \\
\hline 2001 & $56,890.8$ & $57,612.6$ & 8.9 \\
\hline 2002 & $6,615.9$ & $59,311.3$ & 7.9 \\
\hline 2003 & $13,242.1$ & $113,886.6$ & 8.6 \\
\hline 2004 & $18,982.1$ & $233,885.6$ & 11.6 \\
\hline 2005 & $26,493.7$ & $254,707.8$ & 10.1 \\
\hline
\end{tabular}

Source: Securities and Exchange Commission

Table 4.7 shows the performance of equities listed on the Nigerian stock exchange. Considering 1986 and 1987, the trader volume was nil, while trading value stood at 8.6 and 6.1 respectively. 1983 to 1994 stood at 13.5 and 13.0, 16.2 and 12-8, 17.2 and 13.9, 19.2 and 22.0, 23.5 and 27.2, 18.8 and 22.4, 19.5 and 22.9, 52.6 and 87.8, 47.2 and 90.0, 105.7 and 237.1, 186.5 and 286.6, and 190.8 and 401.3 respectively. From 1995 to 2006, the trading volume and value stood at 346.1 and 1,788.1, 733.5 and 6,922.6, 1,160.0 on 10,925.2, 2,080.6 and 13,555.3, 3,913.6 and 14,026, 4,998.1 and 28,146.5, 5,890.8 and 57,612.6, 6,615.9 and 59, 311.3, 13,242.1 and 113,886.6, 18,982.1 and 233, 885.6, 24,493.7 and 254,707.8, and 36,661.2 and $468,588.4$ while the turnover ratio for the various years stood at $0.5,0.3,0.9,0.6,0.5,0.5,0.6$, $0.7,0.4,0.3,0.7,0.5,0.9,0.7,0.7,1.0,2.5,3.9,5.1,4.3,6.0,8.9,7.9,8.6,11.6,10.1$ and 11.1 respectively. The table revealed a tremendous performance in term of trading volume and value with appropriate turnover ratios. Meaning that going into Nigeria stock exchange market will enhance companies' profitability, growth and development. Therefore, Nigerian 
companies have patronized the capital market due to its policies and programmes, particularly in information disclosure.

\section{Test of hypothesis}

Hypothesis-by-hypothesis presentation of results.

\section{Hypothesis One}

Ho: There is no significant relationship between the performance of the Nigerian capital market and the development of the Nigerian economy between, 1986 to 2005.

Hi: There is significant relationship between the performance of the Nigerian capital market and the development of the Nigerian economy between 1986 and 2005.

The independent (predictor) variable $(\mathrm{x})$ in this hypothesis capital market. In this study the predictor variable is sub-divided into three, namely; Government stock (Xi), industrial stock (X2) and Equities (X3). The dependent (criterion) variable (y) in the hypothesis is the development of the Nigerian economy. This brought the total number of variables considered to four, thus requiring a multiple consideration. To make the consideration possible, multiple regression analysis technique was applied. The technique required an examination of the relationship between the single criterion variable and the three predictor variables. In this study the criterion variable (development of the Nigerian economy) has been referred to as GDP (Gross Domestic Product) while the predictors, government stock, industrial stock and equities have been referred to as G5K, 15K and Eties respectively.

Hence the multiple regression equation

$\mathrm{Y}=\mathrm{b} 1 \mathrm{x} 1+\mathrm{b} 2 \mathrm{X} 2+\mathrm{b} 3 \mathrm{X} 3+\mathrm{r}$

$=\quad \mathrm{GDP}=\mathrm{b}(\mathrm{GSK})+\mathrm{b}(\mathrm{ISK})+\mathrm{b}($ Eties $)+\mathrm{r}$

Where: $b=$ Regression coefficient directly associated with the Independent

variables

$r=$ Intercept or constant

The results of the analysis have been presented in Table 4.8

Results of analysis in Table 4.8 show that the calculated f-ratio of 16.23 is higher than the critical f-ratio of 3.00 at 0.5 level of significance with 16 and 3 degrees of freedom. These results imply that there is a composite effect of monetary indices such as in government stocks, industrial stock and equities on the development of the economy.

TABLE 4.8: Regression result of the relationship between performance of thee capital market and development of the economy

\begin{tabular}{lccccc}
\hline \multicolumn{1}{c}{ Variables } & B & $\begin{array}{c}\text { Standard } \\
\text { error }\end{array}$ & Beta & $\mathrm{t}$ & Sig \\
\hline Constant & 733.724 & 728.640 & - & 1.007 & .329 \\
Government stock & 5.118 & 3.943 & 0.375 & 1.293 & .213 \\
Industrial stock & 5.235 & 5.140 & 0.363 & 1.018 & .324 \\
Equities & 0.228 & 0.193 & 0.227 & 1.185 & .253 \\
\hline Multiple $R$ & 0.868 & & & & \\
Multiple R2 & 0.753 & & & & \\
Standard Error of & 1518.1279 & & & & \\
Estimate & 16.23 & & & &
\end{tabular}


Results in Table 4.8 are different especially as they are considered on individual capital market performance basis. The multiple correlation coefficients (R) which measured the strength of consideration between the economic development and capital market performance was 0.868. This correlation coefficient was positive $(+)$ indicating that there was a direct perfect relationship among the variable. This implies that each time stocks and equities increased there was a corresponding increase in the Gross Domestic Product (economic development).

The coefficient of determination (R2), from the result, was 0.753 and it measured the proportion of the variation in the GDP which is explained by the three indices that measured performance in the capital market. This figure implies that $75.3 \%$ of the development in the economy is accountable for by government stocks, industrial stocks and equities while the other $24.7 \%$ is accountable for by other variables extraneous to the study. The results also indicate that none of the variables (predictors) individually predicted GDP as shown in the tvalues (Govt. stock: 1.298, industrial stock: 1.018 and equities: 1.185). None of these t-values was significant at .05 levels. The general result give a regression equation or decision rule as shown below.

$\mathrm{GDP}=5.118 \mathrm{GSK}+5.2351 \mathrm{SK}+0.228 \mathrm{Eties}+733.64$

\section{Hypothesis two:}

Ho: There is no significant relationship between the total number of stocks traded in the capital market and the development of the Nigerian economy between 1986 to 2006.

H1: There is significant relationship between the total number of stocks traded in the capital market and the development of the Nigerian economy between 1986 to 2005.

The independent variable in (predictor) in this hypothesis is the total number of stocks traded in the capital market. The predictor variable is in this hypothesis sub-divided into four, namely; market capitalization (MPS), total volume of stock (VOS), value index of equities (VAS) and listed securities (LNR). The dependent (criterion) variable remained development of the Nigerian economy measured in terms of the Gross Domestic Product (GDP). The variable (y) and four independent (XL, X2, X3 and X4). To test for Significance, the multiple regression analysis technique was adopted to obtain a regression equation that explained the prediction power of the independent variables on the dependent variable.

The prediction equation is given as:

$\mathrm{Y}=\mathrm{bl} \mathrm{Xl}+\mathrm{b} 2 \mathrm{X} 2+\mathrm{b} 3 \mathrm{X} 3+\mathrm{r}$

$=\mathrm{GDP}=\mathrm{b}($ MPS $)+\mathrm{b}($ VOS $)+\mathrm{b}($ VAS $)+b($ LNR $)+r$

Where as usual

$\mathrm{b}=$ Regression coefficient directly associated with the Independent variables

$\mathrm{r}=$ Intercept or constant

The results of the analysis have been presented in Table 4.9

Results on Table 4.9 are different. The individual consideration of the independent variables show clearly that none of the variables was a single good predictor of economic development. The multiple correlation coefficient (R) which measured the strength of association between total number of stock and economic development was 0.934 . This correlation coefficient was positive indicating that there was a direct perfect relationship among the variables. That is, the higher the number of stock the higher was economic development. 
TABLE 4.9: Multiple regression result of the relationship between the total number of stocks traded and economic development.

\begin{tabular}{|c|c|c|c|c|c|}
\hline Variables & $\mathrm{B}$ & Standard error & Beta & $\mathrm{T}$ & Sig \\
\hline Constant & 1116.738 & 1257.636 & - & 0.888 & .389 \\
\hline Market capitalization & 4.719 & 2.812 & 0.828 & 1.678 & .114 \\
\hline Volume of stock & 0.00097 & 0.004 & 0.314 & 0.252 & .804 \\
\hline Value index of Equities & 0.0000076 & 0.000 & 0.275 & -0275 & .775 \\
\hline Listed securities & -6.503 & 52.837 & 0.012 & -0.012 & .904 \\
\hline Multiple $R$ & 0.934 & & & & \\
\hline Multiple $R 2$ & 0.873 & & & & \\
\hline Standard Error of & 1124.860 & & & & \\
\hline Estimate & $25.705^{*}$ & & & & \\
\hline
\end{tabular}

The coefficient of determination (R2) was 0.873 and it measured the proportion of the variation in GDP (economic development) which is resulting from the four indices of total stock. This figure implies that $87.3 \%$ of the development in the economy Resulted from increase in total stock. The other $12.7 \%$ is accountable for therefore by other factors not included in the study. The f-value of 25.705 significant at 0.05 level of significance go to confirm the relationship between the dependent and the independent variable.

The regression equation derived from the results is therefore given or follows:

$\mathrm{GDP}=4.719 \mathrm{MPS}+0.00097 \mathrm{VOS}-0.0000076 \mathrm{VAS}-6.503 \mathrm{LNR}+1116.738$.

\section{CHAPTER FIVE}

\section{SUMMARY OF FINDINGS, CONCLUSIONS AND RECOMMENDATIONS}

This chapter is designed to present the summary of findings and conclusion based on the analysis of the hypotheses that directs the study. Recommendations will also presented in this chapter

\section{Summary of findings}

The main objective of this research was to examine the performance of the Nigerian capital market in the development of the Nigerian economy from 1986 to 2005. Data collected and analyzed indicated that:

i. The listed securities in the capital market maintained a steady increase as was observed from 2000 to 2005 respectively which also shows that the price changes in the Nigerian stock market are more systematic than random in movement over time.

ii. The Nigerian capital market operations was efficient with the context of the performance of the capital market hypothesis which implies that each time stocks and equities increased there will be a corresponding increase in the development of the economy (GDP).

iii. The introduction of new shares in the capital market has brought growth and development of the Nigerian capital market. This development has gingered the utilization of the Nigerian capital markets functions by Nigerian companies as well as individual investors.

From the study it has been established that the Nigerian capital market through the stock exchange established in the states has fulfilled its functions of providing facilities for dealing in listed securities, overseeing the trading of those securities and ensuring four pricing of securities, establish rules regulating transfer of shares and initiating measures of encourage savings and issuance of securities by government and other organizations. 


\section{CONCLUSIONS}

In conclusion, the capital market specifically provides funds to industries and governments to meet their long-term capital requirements for fixed investment like buildings, plants and machinery and other public infrastructures.

Empirical research however, indicates that the role of the Nigerian capital is limited. This is shown by its low contribution to the level of capital mobilization and investment as evidenced by the low market capitalization over the sphere in review. Although the federal government had complemented the role of the Nigerian stock exchange through the establishment of some key development finances institutions to provide specialized long-term capital for sectoral growth and development the impact has not been fully felt.

With the recent reforms in the economy, particularly in the banking sector, there is need for the capital market to develop the required resilience towards evolving a financial infrastructure that would engender economic growth and transformation in the economy.

Finally, there is an obvious challenge to urgently develop a vibrant bond market to allow the private sector access to a larger number of best instruments in order to enhance the management of their liabilities.

However, in real world conditions for maximum efficiency in performances are unlikely to exist. Yet even though this conditions may not be fulfilled, in practice with the reforms and globalization performances will be enhanced and realizable if sufficient participants have equal access to adequate stock information.

Given the position the Nigerian capital market cannot be said to have perform excellently as the need for further review becomes apparent when compared to other countries of the world.

\section{RECOMMENDATIONS}

In the study an attempt has been made to provide a theoretical and empirical analysis of the performance of the Nigerian capital market. Results indicate that performance of the Nigerian capital market to a large extent has contributed to the development of the Nigerian economy and has provided the opportunity for a given class of investors to finance and expand their business. This feat notwithstanding it is obvious that the capital market is still faced with more challenges which requires the following recommendations:

There is need to evolve comprehensive measures to strengthen, broaden and deepen the market to enhance its intermediary role in financing economic activities. The accelerated upgrade of systems need to be sustained while the regulatory and prudential framework should continuously be reviewed to facilitate better disclosure standards and transparency for transactions.

i. There is need to open up the capital market and promote free flow of information in its operations as it is the case in other countries: firms listed on the stock exchange should be published quarterly and half-yearly reports in addition to annual reports on their operations with detailed explanations on the drivers of the performances.

ii. The challenges of low awareness about the operations and benefits of the capital market in the economy should be looked into. The level of awareness of the populace about the capital market and the opportunities available in it would enhance the level of their participation in the market. 
iii. The capital market should be at the forefront of ensuring financial integrity in order to minimize the potential effects of the risk of contagion as well as reduce systemic risks. Thus, there is the compelling need to strengthen the enforcement of the corporate governance code among listed companies which is essential for promoting investor confidence and inducing sustained long-term growth of the capital market. In this regard, the proactive stance of the management of the Nigerian stock exchange and the Securities and Exchange Commission in their respective efforts at raising the standards of capital market operators should be sustained.

iv. There is need to take the capital market window to more towns and cities in Nigeria for greater width and enhanced growth. Improvement in the availability of social infrastructure such as electricity and media equipment in homes would boost nationwide information dissemination.

v. There is need to canvass for self-regulation in the institutions of the capital markets as well as the cooperation and full commitment of operators towards a high level of professionalism and high ethical standards. In this regard, the imposition and enforcement by the regulatory authorities would be a welcome development. The years ahead would be increasingly demanding and competitive, and only the adoption of good corporate governance by institutions, market participants and intermediaries can guarantee sustainability.

vi. The issue of investors' perception is very important. The decision to invest in a financial instrument or indeed in the securities market or a particular company is usually influenced by perception. A good perception of a company, a country or region attracts investment into it, while poor perception would undoubtedly impact negatively on the level of investment. International perception of a country's political and economic environments is often a strong influence on the response of foreign investors to its security offering. With the return of democratic rule and the reforms in the economy, particularly in the banking sector, coupled with the establishment of the Economic and Financial Crimes Commission (EFCC) and the Independent Corrupt Practices Commission (ICPC), the confidence of both local and foreign investors in the economy is gradually returning. There is therefore a compelling need to sustain these reforms.

vii. There is need to review the regulatory framework in line with international best practices to entrench market rules and principles that would enhance good corporate governance in system. The existence of such market rules attracts public confidence for the market.

viii. The regulators of the capital market should encourage more derived financial products such as pension funds and mutual funds, which could serve as vehicles for mobilizing funds for investments on the stock market.

\section{References}

Adetunji, W. (1977). Money and capital markets in the economy. Including the role of money market institutions. Central Bank of Nigeria Economic and Financial Review. 31 (1), 13-19

Agarwal, R.N (1997). Inflow of foreign portfolio investment in developing countries. A study of determinants of macroeconomic impact. The Indian Economic Review 32(2), 217-229

Ahmed, (1992). The role of Central Banks in capital development: The Nigerian experience. Bullion Publication of the Central Bank of Nigeria, 16(4):21-25.

Akamiokhor, G (1992). The role of regulatory bodies in capital market development: The Nigerian experience. Bullion Publication of the Central Bank of Nigeria, 16 (4), 26- 31.

Akingbohungbe, S.S. (1990). The role and impact of Securities and Exchange Commission in the economy. Nigeria Securities Market Journal. 6(2), 31-40.

Akpan, 1. (2004). Fundamental of finance, Uyo: Nelgrafik press. 
Duke, S. B., \& Nkamare, S. E. (2015) impact of capital Market on the Development of the Nigerian Economy. Archives of Business Research, 3(4), 124-151.

Akpan, O.E. (1995). Thin and thick capital markets: empirical test of evidence I for the Nigerian stock exchange in Nigeria. Journal of Economic and Social Studies, 37 (1) 65-69.

Anyanwu, D.C. (1998). Stock market development and Nigeria's economic growth. The Nigerian Journal of Economics and Social Studies. 1 (2) 4-7

Anyanwu, J.C., Oyefusi, A., Oackhenan, H. \& Dimowo, F.A. (1997). The structure of Nigerian economy 1960-1997. Onitsha: Joanee educational publishers

Asika, N. (1991). Research methodology in the behavioural sciences. Ikeja: Longman

Ayadi, O. (2006). Random walk hypothesis and the behaviour of stock prices in Nigeria. The Journal of Economics and Social Studies, 1 (25), 7-8.

Babalola, J.A (2001). The performance of the Nigerian capital market since deregulation in 1986. Central Bank of Nigeria Economic and Financial Review. 39(1), 1-19

Babutsidze, Z. (2004). The critical assessment of the empirical evidence on the imperfection of capital markets. The Nigerian Journal of Economics and Social Studies. 4 (2) 14-20

Branes, P. (1986). Thin trading and stock market efficiency: A case of the Kuala Lumpur stock exchange. Journal of Business Finance and Accounting 13(4) 10-50.

Briston, E (1969), financial structure and economic development. Economic Development and Cultural Change, 15 (1) 257-268.

Cho YJ. (1986). Inefficiencies from financial markets in the absence of well functioning equity markets. Journal of Money, Credit and Banking, 18. 14-23

Copeland, T.E. \& Weston J.F. (1983). Financial theory and corporate policy. New Jersey: Prentice-hall incorporated Demirguc-Kunt .A. \& Makgimovic, V. (1996). Stock market development and financing choices of firms. World Bank Economic Review, 10 (15) 236-245.

Demirguc-Kunt, .A. \& Levine, R. (1996). Stock markets, corporate finance and economic growth. World Bank Economic Review, 10: 412-19.

Donald E.F. \& Ronald J.J. (2006). Security analysis and portfolio management, New York: Pearson education, Inc. and Darling Kindersley publishing Co.

Dryden, M. (1970). A statistical study of United Kingdom share prices. Scottish Journal of Political Economy, 2 (36): $41-$ 46

Edogi J. (2006). Stock market investment and strategies. Don-Hill: Nigeria enterprises

Ekineh O. (2000). The Nigerian capital market; present and future challenges. Paper presented at a workshop on legislating for capital market in a democratic environment organized by the Securities and Exchange Commission, Nicon Hilton Hotel Abuja, and Oct. 12.

Ekpenyong D.B. (1994). Investing in securities in Nigeria the investor's guide. Uyo: Linnet Palil publications

Etuk, E. J (2003). Business research method. Calabar: University of Calabar Press

Fama, E.F. (1965). The behaviour of stock market prices. Journal of Business, 2 (38) 20-22

Fama, E.F. (1970). Efficient capital market: A review of theory and empirical work: Journal of Finance, 4 (5), 18-20

Fobbozzi, F.J. \& Modileani, F. (1992). Capital markets institutions and investments, London: Prentice -Hall

Foley, BJ. (1999). Capital market, London: Macmillan

French, D.W. (1989). Security and portfolio analysis, concepts and management: London: Merrill publishers.

Giwa, M. R. (1990). Stock markets. A spur to economic growth, financial and development. Journal of Finance, 41 (3)1520

Gordon, MJ. (1962). Investment financing and valuation of Corporation. Homewood: Richard Irwin 
Hananna, H (2004). Equilibrium in a capital asset markets, Econometrical, 1 (2), 1- 6.

Husain, F. \& Kelvin, F. (1999). Efficiency in a thinly traded market: The case of Pakistan savings and development. Journal of Financial Economics, 2l (1), 26-32

Jensen, M. (1978). Some anomalous evidence regarding market efficiency. Journal of Financial Economics, 3(6), 12-17

Kadiri, A.O. (1983). Pricing in capital market. Bullion Publication of Central Bank of Nigeria 8(4):24-30

Keane, S.M. (1989). Seasonal anomalies and the need for perspective. The Investment Analyst, 91: 32-35

Kein, D. (1984). Size related anomalies and stock return seasonality: further empirical evidence. Journal of Financial Economics, 12: 6-10

Kendall, c.c. (1988). Capital markets development. Finance and Development, 4:32- 36.

Levine, R. \& Zervos, S. (1996). Stock market development and long-run growth. The World Bank Policy Research Working Paper. 1582: 688 - 726.

Levy, E. S. (1967). Financial depending in economic activity. New York: McGraw-Hill

Lumby, S. (1994). Investment appraisal and financial decision. London: Chapman \& Hall Publishers

Mbat, D.O \& Udoka C.O (2008). Weak form market efficiency: dynamic effects of information on the Nigeria stock market, 1986-2004. African Journal of Contemporary Issues 8 (8): 44-56

Mbat, D.O. (2001). Financial management, Uyo: Domes Associates

Nnanna, C.E. (2004). Financial markets in Nigeria. Journal of Financial Economics, 41 56-65

Nwankwo, G.O (1980). The Nigerian financial system. London: Macmillan

Nwankwo, K (1993). Financial market institution: A managerial approach.Retrieved on 15 August 2008 from www.financialmanegment

Nzotta, S.M. (2004). Money banking and finance (theory and practice). Owerri, Hudson Jude, Nigeria publishers.

Okereke, O. (2000). Investment decisions. Retrieved on 17 July 2008 from www.nigerianfinancialsystem

Onoh, J.K (2002). Dynamics of money, banking \& finance in Nigerian emergence market. Lagos: Astra meridian publishers

Onyido, 0 (1994). The Nigerian stock market in operation. Ikeja: Jeronme Larito and associates.

Osaze, E.A. (1997). The development of capital markets in Africa with particular reference to Kenya and Nigeria. International Monetary Fund Staff Papers, 18 (2) 420 - 476.

Osei, K. (2002). Assets pricing and information efficiency of the Ghana stock market. African Economic Research Consortium Research Paper; 58.115, 1-15.

Osisoma, B.C., (1989). Capital market efficiency in Nigeria. Unpublished PhD thesis carried out in the Faculty of Management Sciences, University of Nigeria, and Nsukka

Prateen C. (1993). The Stock Market... Cambridge: Syndicate Press

Ronald, C. \& Grandbois C. (1999). Performance of the securities exchange of Barbados, savings and development. Retrieved October 72008 from .www.brookings.edu.

Sharp, W.F. (1964). Capital asset prices A theory of market equilibrium under condition of risk. Journal of Finance, 4 (10), 20-21.

World Bank (1996). Exchange rate expectation and portfolio investment. Retrieved on July, 172008 from www.worldbankfinancialreport 